\title{
FOREWORD TO THE FIFTEENTH ANNIVERSARY ABRIDGED EDITION
}

\author{
Moss Roberts
}

One way to approach a subject as vast and complex as China's culture and history is to organize their grand canons into three or four main clusters. First and foremost should be the formative preimperial philosophical classics: the Confucian worksthe Analects, the Mencius, and the Xunzi-and the writings of the Mohists, Daoists, and Legalists, the earliest critics and adversaries of Confucian thought. All of these works of statecraft, social morality, and cosmological speculation covering ca. 500-200 B.C., the Warring Kingdoms period, build toward and lead into the unification of the kingdoms under a single dynasty, the Qin, followed in fifteen years by the Han, which lasted for more than four hundred years, until A.D. 220. Three Kingdoms offers a reverse perspective, from the fall rather than the rise of the Han, revealing the factors and forces that can cause a dynasty to break down and lead to a period of disunity. As a critique of imperial authority, Three Kingdoms is also altogether different from the Aeneid, which builds toward the founding of a great empire and celebrates Augustan rule.

The writings of the Warring Kingdoms period and the culminating unification of 221 B.C. may be looked on as the foundation of the institutions and philosophical traditions that created the China still known today. Confucius, who died in 479 B.C., predicted the continuity of Chinese traditions and institutions when a student asked about the shape of the future. In his sly way, Confucius pointed first to the deep past to show how $l i$ ("ritual," or time-honored forms and formalities of culture) had already descended through many centuries to his own time with but minor modifications, and then went on to assure the student that even 
the remote future would not be all that different, provided that $l i$ continued to shape the course of the culture. It is thus less the political circumstances and types of rule than the education and temperament of the people that define China. That is why the country's name contains the word zhonghua, not zhongguo. Hua means "flourishing" and suggests culture, while guo suggests territory and who rules it and has a military weapon in its graph.

The major novels constitute the second cluster: the Shuihu zhuan (Outlaws of the Marsh), the Xiyou ji (Journey to the West), the Honglou meng (Dreaming in the suites of worldly passion), and the Sanguo yanyi (Three Kingdoms, offered in the present abridged translation). These novels, apart from their inherent interest as literature, are important for how they draw on traditional themes of religion and philosophy. For one example, Three Kingdoms largely depends on Mencius's theories of leadership and also has Daoist components. The team of Liu Xuande and his main adviser, Kongming, operate within a synthesis of Confucian and Daoist-Legalist ideas. At one critical moment Kongming summons a great fog to conceal a naval counterattack. This obliteration of all visible signs is described in language drawn from Daoist texts, as if Kongming had conjured the immaterial Dao itself down to earth. Buddhism too has a role in Three Kingdoms, though it did not enter China until about two hundred years after the unification and thus was never a part of Warring Kingdoms culture.

Third, it is essential to know something about China's history over the past century or two and its interrelations with Korea, Japan, and Vietnam. During this time span, the Republican Revolution (1911) put the two words of its name on the historical agenda that has defined the modern period in China and Asia. That year was when the goals of national independence and freedom from Western domination and dynastic despotism determined the direction of China's history. This in part explains why a "historical" novel like Three Kingdoms remains a staple of China's literary and popular culture: if national unity is the precondition for national independence, then the story of how a dynasty, the Han, that endured for more than four hundred years and gave its name to the main Chinese ethnicity finally fragmented into three warring kingdoms offers insights, lessons, 
and applications for all eras. After 1911 the Manchu dynasty abdicated and China was divided into warlord "kingdoms." Unity was restored only after and through the Communists' revolution, a major factor underlying the legitimacy of their rule. Three Kingdoms too traces the passage from unity to disunity (three kingdoms) and then back to the unity of 280 A.D., when the Jin dynasty ruled the land, albeit for only a generation. That the author ends the novel in 280 A.D. is significant for reasons explored in the afterword.

Early in the period of Communist rule, the novel Outlaws of the Marsh enjoyed wide attention thanks to its theme of rebellion against dynastic power followed by reconciliation with that power. But Three Kingdoms is more conservative and dynastic in its political thinking than the revolutionary Shuihu, since it begins with a suppressed rebellion. However, after three decades of relative neglect (1950-80), Three Kingdoms reemerged as a major subject of interest in China, a position it still holds. The novel is also well known in Japan, Korea, and Vietnam, the other three nations of "Confucian Asia," where centralized government over a unified territory is considered the wholesome norm.

One might add to this preliminary list of key clusters Buddhism and Chinese poetry, not only because they pervade the language and thought of Korea, Vietnam, and Japan as well as China but also because Buddhism and poetry have an important function in the novels, including Three Kingdoms. This novel contains more than two hundred poems, and one major character, Lord Guan, undergoes posthumous conversion to the Buddhist law after his execution. One can look at Three Kingdoms as a consummation of many Chinese traditions and as a gateway to those traditions. For Western readers, Three Kingdoms is perhaps more embedded in China's culture and history than the Shuihu zhuan or the Honglou meng. The latter two are to a degree separately accessible. Similarly, the Dao De Jing has a wide foreign readership apart from its own context, while the Analects of Confucius (like Three Kingdoms) does not migrate easily into other literary or academic cultures.

Is Three Kingdoms a work of history or fiction? Clearly both, but not equally. The novel has a large historical component, perhaps three-quarters of the whole. Yet the fictional elements shape the entire narrative. The peach garden oath begins the story, as three 
heroes declare themselves brothers and vow to save the failing Han dynasty from rebels. One of the three, Lord Guan, has a minimal historical presence. It was mainly in the Yuan dynasty, which preceded the Ming, that his status was lifted to God of War. The novelist has built important parts of the narrative around a fictionalized Lord Guan, often drawing on the many dramas in the Mongol (Yuan) period devoted to him and infusing the narrative with dramatic writing. This character serves the reader as a kind of "red thread" that organizes the narrative. And, as if to highlight Lord Guan's imaginary existence, the author permits him to survive his death. By contrast, one of the kings, Liu Xuande, and his chief adviser, the strategic genius Kongming, are characters rather closely dependent on historical records. The synergy of history and fiction lifts the novel above both categories. Quantitatively the work is historical; qualitatively it is fictional.

Wherein does its appeal lie? Partly in the author's skill in moving the reader seamlessly between the two realms of history and fiction. Since official history often conceals more than it reveals, the novel's dual modes allow the author to go behind the scenes of decision making in war and diplomacy, virtually breaking through the fourth wall to re-create the unseen machinations of power. In modern terms, it is the difference between public relations transcripts and real-time video or tapes. The reader can grasp the whole of power in operation while bearing witness to the limitations of power and the destructive delusions of the powerful.

Chinese often identify with characters in the novel, as if it is read in part as an account of historical reality. Since working on this translation in China in the early 1980 os I have been asked which of the various heroic figures I most admired or who I thought played the most important part. Invariably it was men asking the question, clearly with the expectation that I would name Kongming, the genius of strategy; the indomitable warrior of unshakeable commitment Lord Guan; or the man who should be emperor, Liu Xuande. Even the sinister but Napoleonic Cao Cao was seen as an impressive role model. The opposition of these last two protagonists, both of whom have the qualities to rule the Han dynasty, though neither takes the throne, structures the entire 
narrative. Even after their deaths two-thirds of the way through the story, the kingdoms that each founded, Shu and Wei, continue the characters' opposition.

To the disappointment of my Chinese questioners, I never held up any of these major characters, citing instead Diaochan, the adolescent geisha whose seductive artistry brings down two villains. For none of the major figures fulfills his mission: only Diaochan fulfills hers, successfully turning two villains against each other at the behest of her adoptive father, the high minister Wang Yun. Thus her filial service to parent and dynasty clears her of the classical charge of venery directed at women. Occasionally this response was accepted.

The story of Diaochan, taken from Yuan theater, is placed in chapters 8 and 9 of a work running to 120 chapters. She is inserted into the narrative early to show a young woman eliminating a pair of tyrants from high government office, a feat three great warriors fail to accomplish in a preceding chapter. The Diaochan episode affects the reading of the rest of the novel, calling into question the achievements of history's heroes.

The opening poem was added to the Qing dynasty edition, the one universally known, and serves to suggest the larger meanings of the tale. ${ }^{1}$ Its first lines depict the river of time, which overpowers history and its heroes, adding a Buddhist caution against vanity by negating human achievement and pretention. The first words, gun-gun ("rolling, rolling on"), contain a graph with water on the left and a patriarch in his robes on the right. The visual impact is direct: men of high status in official dress are tumbling head over heels in the onrush of the Yangzi River as it runs eastward and then bends out of sight. In the second line the force of the white-cresting waves scours off all trace of the heroes of the age. In line 3, the triumphs and the judgments of human history turn all at once to naught, or kong, the Buddhist term for the evanescence of material visible forms. All that is left is water, and the green hills of earth-that is, the jiang-shan, which is the world of nature, habitat of the common folk. The jiang-shan is different from the tianxia, the world under heaven, which is the political world ruled by the tianzi, or Son of Heaven. Tianxia changes, but the jiang-shan remains. In the second stanza 
the "famed events" of history are relegated to the barroom jests of the common folk in their hour of conviviality. And thus the poem introduces the novel, which in the complexity of its judgments and the uncertainty of its endings bears some resemblance to the problem plays of Shakespeare. ${ }^{2}$

\section{NOTES}

1. An earlier, Ming edition was not discovered until the twentieth century. Footnotes in the unabridged edition detail many of the important variations between the two.

2. For further commentary, see the translator's foreword, "The Language of Values in the Ming Novel Three Kingdoms," in "Three Kingdoms" and Chinese Culture, edited by Kimberly Besio and Constantine Tung (Albany: State University of New York Press, 2007), vii-xiv. 